\title{
An American librarian in Kuwait
}

\author{
By C. Kelly Brewin
}

Assistant Director for Public Services

Texas Southmost College

\section{An adventure ends abruptly.}

W hen Iraq invaded Kuwait on August 2, 1990 , I was visiting friends in Mainz, Germany, and planning to fly back to Kuwait the following day. The moming news over the American Forces News Network was a complete surprise; I was totally unprepared for the invasion. As the days passed, I saw my world crumble about me. In a matter of hours, I had lost my means of livelihood, my home, and many friends.

I had left Louisiana in November, 1987, as a member of a task force of five American librarians employed as consultants to assist in upgrading library services and automating library functions at Kuwait University Libraries. During our first three weeks in Kuwait, we attended an intensive orientation program that stressed the cultural differences we would find and cautioned us that we would be judged as Americans in our work performance. If we were to be successful, we were told, our proposals for change would have to be accepted as good librarianship rather than expressions of American values or culture.

Kuwait University, we learned, was established in 1966 and grants baccalaureate and masters' degrees. The languages of instruction are Arabic and English. About 10,000 students attend the university, which consists of five campuses, each with one or more colleges affiliated with one of the eight individual libraries: Science, Engineering, Commerce and Political Science, Law, Education, Arts, Islamic Studies, and the Women's College. There are separate facilities for Kuwait and Gulf Archives, Audiovisuals, and Manuscripts.

Within this decentralized structure two parallel library systems had developed, one Arabic and the other non-Arabic. The Arabic Cataloging Department used a modified Dewey Decimal Classification. Each library maintained two shelflists, two card catalogs, and two shelving sequences. The collection of approximately 500,000 volumes was equally divided between Arabic and non-Arabic titles.

Because library personnel were not bilingual, every library function had two complete staffs. Several nationalities were represented, including Kuwaitis, Egyptians, Palestinians, Pakistanis, and Indians. Academic credentials varied from two years of high school to a doctorate. Four Kuwaiti librarians had MLS degrees from American institutions; most of the other librarians held a BA or a BLS from Arab universities. The challenges involved in training two distinct staffs that could not function in both systems and had very different levels of education were daunting. We spent the first six months acclimating ourselves to our new environment, getting to know the different librarians, and documenting the libraries' procedures and services. By concentrating our efforts in the nonArabic system, we hoped to create an efficient and effective model which could be duplicated in the Arabic system.

My initial task was to develop circulation policies and procedures. At the time, there was no uniform policy: each college library acted as a separate entity rather than an integral part of Kuwait University Libraries, and patrons were treated differently from one library to the next. As I visited the libraries and interviewed each head librarian, I realized that there was a vast difference between current American and Kuwaiti library practice. 
The policy which eventually grew out of these discussions represented a compromise between the two positions.

Despite the cultural differences, I was constantly surprised by how well I was adjusting. In fact, I began to regard Kuwait as my home. I lived in a seven-storied apartment building in one of the suburbs of Kuwait City, and since I was not restricted to a foreign compound, it was easy to meet local people. Most of them spoke some English, which is the language used for business in Kuwait.

Though I was always surprised by how Americanized the environment seemed, Kuwait has sent many university students abroad, often to the United States. Many people I met seemed like Arab-Americans to me. One of my new friends had attended the University of New Orleans and had lived in Fat City.

One reason I felt at home was that Cajun cooking had reached Kuwait. I sometimes shopped at Safeway, where I could buy my favorite Zatarain's crab boil. Kuwaitis love fresh seafood: Kuwait developed out of a fishing village, and many $\mathrm{Ku}-$ waitis are still fishermen. Fresh seafood markets are everywhere, offering shrimp, crabs, and a great variety of fish, at prices quite similar to prices in Louisiana. Other favorite Louisiana staples are also widely consumed, such as rice, okra, and every kind of Louisiana hot sauce. On a weekend trip to Dubai in nearby United Arab Emirates, I walked into a shopping mall that had a Popeye's Chicken franchise.

Food was not the only cultural export I found. The American literature section of Kuwait University's Arts Library had copies of John Toole's first published novel and almost a complete collection of Walker Percy's novels. I never found the person responsible for showing such good Southem taste by ordering these books!

Although Kuwait shares the same latitude as New Orleans, their environments contrast starkly: one is surrounded by swamp and the other by desert. Weather is a common topic of conversation. Rain-or rather, the lack of it-is on everyone's mind. In summer you know that the weather will be hot when you wake up and when you go to bed. Your routine consists of rushing from your airconditioned apartment to your airconditioned car to your airconditioned office and back again. January and February are the coolest months, and sometimes the wettest.

Kuwait's culture is thoroughly Arabic, but it includes many of our basic values. The most important social unit is the family: households often included members of different generations, and in fact, the extended family seemed to cover all

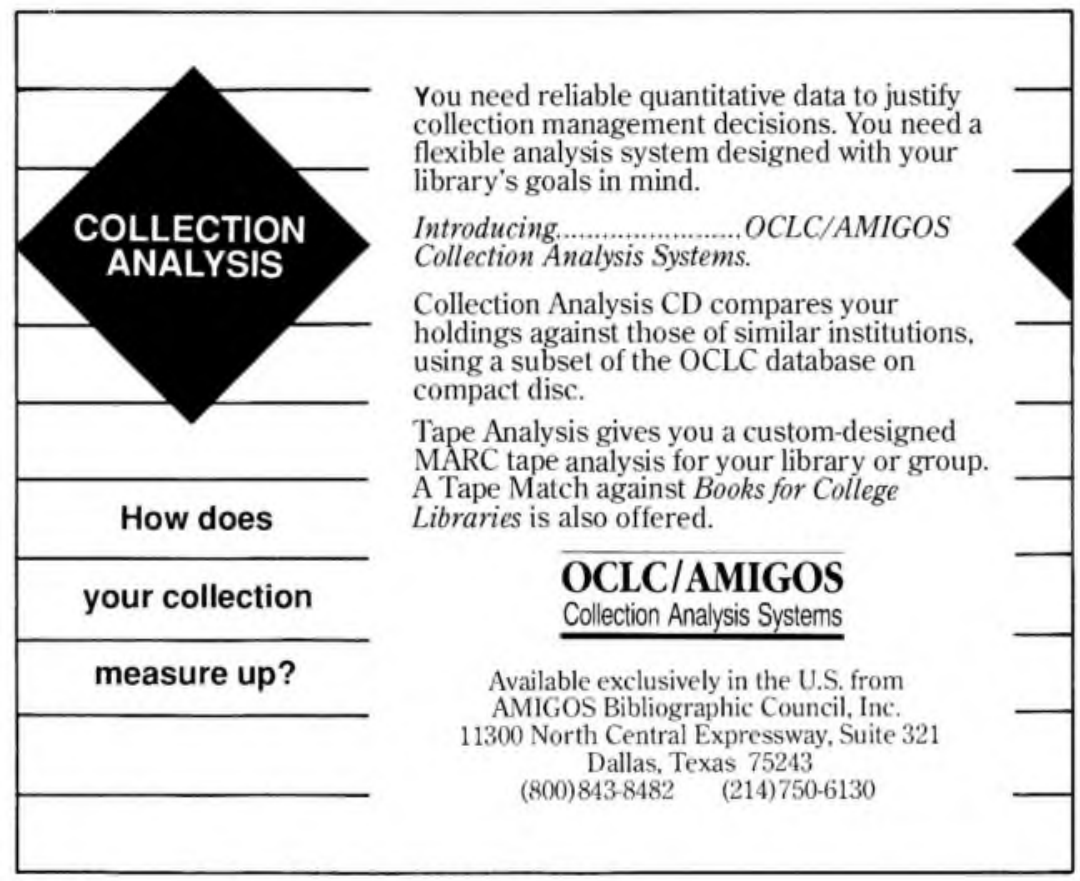


members of the tribe to which the family belonged. Arab hospitality is renowned. Sharing a cup of tea or coffee before any business is transacted is almost mandatory. Politeness is universal. Kuwaitis practice a mixture of formal and informal manners that reminded me of my Southern childhood, during which $I$ addressed my elders by their first names preceded by "Mister" or "Miss." In Kuwait I was always called "Mr. Kelly."

Kuwait's bureaucracy was formidable. My American colleagues were always frustrated when

\section{ACRL Task Force to aid Kuwait}

William A. Moffett, ACRL past-president (Huntington Library) has been appointed by ACRL President Barbara J. Ford (Trinity University) to head up an ACRL task force on relief for Kuwaiti libraries. The task force will investigate how American libraries might play a role in helping restore Kuwaiti libraries in postwar Kuwait.

The task force is seeking volunteers interested in helping organize appropriate assistance for the Kuwaiti libraries. Librarians with experience working in the Middle East or with knowledge of Middle Eastern libraries are especially needed. The task force will organize efforts to help and work with Kuwait officials to ensure the assistance is provided where it is most needed.

Mohammed Abdul-Karim Al-Shatti, the director of the Kuwait Department of Libraries, had approached Moffett during the 1990 ALA Annual Conference in Chicago and solicited his assistance in improving Kuwaiti libraries. The ensuring Persian Gulf War interrupted plans for providing assistance to the Kuwaitis, but now the assistance is more urgently needed.

"We need to find out whether Mr. Al-Shatti or someone else is now in a position to respond to our inquiries about what is needed," Moffett says. "We need to know which are the appropriate agencies through which we might communicate effectively; we need to know who in our profession is knowledgeable about the Middle East and interested in becoming actively involved in a relief effort."

Interested persons should contact William A. Moffett, The Huntington Library, 1151 Oxford Road, San Marino, CA 91108; (818) 405-2175; fax: (818) 405-0225; e-mail: moffett@caltech. The task force's plans and activities will be reported in upcoming issues of CorRL News. they had to process any official business. Their responses were all too familiar to me, reminding me of the exasperating experience of going to New Orleans City Hall to apply to have water connected, or obtaining a car inspection tag in Orleans Parish.

Kuwait's population included many national groups. Strolling down a street in Kuwait City was similar to walking through the French Quarter, where one hears a variety of languages spoken by visitors from around the world. In fact, as I look back over the last three years, I realize that the many familiar things I discovered in Kuwait helped me to adjust to living and working there and finally to accept Kuwait as my home.

By the end of July 1990, we had accomplished several of our initial goals. Kuwait University Libraries now had many written policies and procedures, a modern reference department was functioning, and a training program was in place. NonArabic collections had been evaluated and weeded. A non-Arabic shelflist had been prepared for conversion to machine-readable format. The non-Arabic Cataloging Department had changed to the Library of Congress Classification and was prepared to begin online cataloging. Proposals for bids on an integrated online system had been mailed. All processing of monographs had been centralized in cataloging, thereby reducing staff duplication, improving quality control, and standardizing materials. (That was one of the few changes that could be accomplished in both systems.) It seemed like a good time to take a vacation. I left Kuwait City, not dreaming that I would never return.

Ed. note: Part of this article previously appeared in LLA Bulletin 53(3), Winter 1991.

\section{ALA student membership}

ALA, in coordination with the leaders of the 26 official ALA student groups, has published a brochure, "Put ALA on Your Resume: A Guide for Student Members." Topics include ALA's Placement Center, student member dues, discounts on publications and graphics, student chapters, involvement in ALA, and the professional support offered by ALA's program offices. Students are also advised on how to receive copies of the ALA Checklist of Publications and the ALA Handbook of Organization, and where to find the complete list of ALAsponsored scholarships and awards. The free brochures are available from the deans of ALAaccredited library schools, officers of student chapter groups, and Katherine G. Wilkins, Membership Promotion, Membership Services, ALA, 50 E. Huron St., Chicago, IL 60611. 